\title{
Proximate Composition and Effect of Processing on Protein Quality of Minor Cereals Grown in Sri Lanka
}

\begin{abstract}
Ei
Karanagala Pathiranage Gayani Udyoga Samarasinghe
\end{abstract}

Thesis submitted to the University of Sri Jayewardenepura as the partial fulfilment requirement for the award of the degree of Masters of Science in Food Science and Technology. 


\section{Declaration}

The work describe in this thesis was carried out by me under the supervision of Mrs.D.Rajapaksha,Dr.Sagarika Ekanayake and Dr.K.K.D.S.Ranaweera and a report on this thesis has not been submitted in whole or in part of any University or any other institution for another degree.

K.P.G.U.Samarasinghe

Q...samaras!ng.t....

Signature

$. .3 .03 .09 . .0$

Date 
We certify that the above statement made by the candidate is true and that this thesis is suitable for submission to the university for the purpose of evaluation.

\section{Internal supervisor}

Dr. K.K.D.S. Ranaweera,

Head of Department of Food Science and Technology,

University of Sri Jayewardenepura,

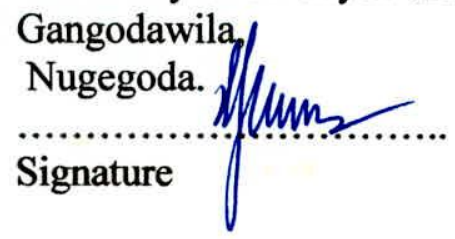

\section{External supervisor}

Mrs. D. Rajapaksha

Senior Research officer,

Agro and Food Technology Division, Industrial Technology Institute,

No 363, Bauddaloka Mawatha,

Colombo 07.

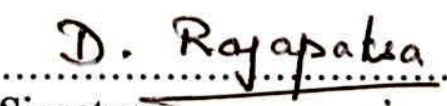

Signature

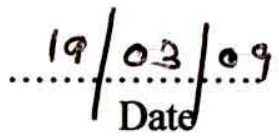

Dr.Sagarika Ekanayake,

Senior Lecturer,

Department of Biochemistry,

Faculty of Medicinal Sciences,

University of Sri Jayawardenepura,

Gangodawila,

Nugegoda.

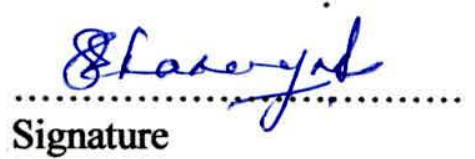




\section{Contents}

Content

List of tables $\quad$ v

List of figures vi

Acknowledgment vii

Abstract viii

Chapter 01 Introduction

1.1 Introduction 1

1.2 Objectives 2

1.2.1 Specific Objectives 2

\section{Chapter 02 Review of literature}

2.1 Kurakkan - (Eleucine coracana) 3

2.1.1 Introduction 3

2.1.2 Habitat and distribution 3

2.1.3 Botany of the plant 4

2.1.3.1 Taxonomy 4

2.1.3.2 Description and Morphology 4

2.1.4 Nutrition $\quad 5$

2.1.5 Food uses 5

$\begin{array}{ll}\text { 2.2 Meneri (Panicum miliaceum L.) } & 8\end{array}$

2.2.1 Introduction $\quad 8$

2.2.2 Habitat and distribution $\quad 8$

2.2.3 Botany of the plant $\quad 8$

2.2.3.1 Taxonomy 8

2.2.3.2 Description and Morphology 9

2.2.4 Nutrition 11

2.2.5 Food uses 11

2.3 Sorghum (Sorghum vulgare-L) 12

2.3.1 Introduction 12

2.3.2 Habitat and distribution $\quad 12$

$\begin{array}{ll}2.3 .3 \text { Botany of the plant } & 13\end{array}$

$\begin{array}{ll}2.3 .3 .1 \text { Taxonomy } & 13\end{array}$ 
2.3.3.2 Description and Morphology

2.3.4 Nutrition

2.3.4.1. Carbohydrates

2.3.4.2. Proteins

14

2.3.4.3. Lipids

15

2.3.4.4. Vitamins and Minerals

2.3.5 Food uses

2.3.6 Other uses

2.4 Thanahal (Setaria italic-L)

2.4.1 Introduction

2.4.2 Habitat and distribution

2.4.3 Botany of the plant 18

2.4.3.1 Taxonomy 18

2.4.3.2 Description and Morphology

2.4.4 Nutrition 20

2.4.5 Food uses 21

2.5 Protein quality 21

2.5.1 Protein efficiency ratio 22

2.6 Anti-nutritional factors 22

2.6.1 Tannins (condensed polyphenols) 23

2.6.2 Cyanogenic Glycosides 24

2.6.3 Phytate 24

2.6.3.1 Effect of phytate in nutrition 25

2.6.3.2 Protein -phytate interaction 25

$\begin{array}{ll}2.6 .3 .3 \text { Reduction of phytic acid } & 27\end{array}$

Chapter 03 Material \& Methods

3.1 Sampling

3.2 Chemical analysis (proximate composition)

3.2.1 Sample preparation for chemical analysis

3.2.2 Moisture determination

3.2.2.1 Materials

3.2.2.2 Methods

3.2.3 Fat determination $\quad 30$

3.2.3.1 Materials 
3.2.3.2 Method $\quad 30$

3.2.4 Protein determination 31

3.2.4.1 Materials 31

3.2.4.2 Methods 31

3.2.5 Crude fiber determination $\quad 32$

3.2.5.1 Materials 32

3.2.5.2 Method 33

3.2.6 Ash (mineral) determination $\quad 33$

3.2.6.1 Materials 33

3.2.6.2 Method 34

3.2.7 Carbohydrate determination of carbohydrates by difference $\quad 34$

3.2.8 Iron determination-Spectrophotometric method 35

3.2.8.1 Materials 35

3.2.8.2 Method 35

3.2.9 Calcium determination-Atomic absorption method 36

3.2.9.1Materials 36

$\begin{array}{ll}\text { 3.2.9.2 Method } & 37\end{array}$

3.3 Determination of Protein Efficiency Ratio-Rat Bio assay 37

3.3.1 Determination of Protein Efficiency Ratio-Raw cereal 37

$\begin{array}{ll}\text { 3.3.1.1 Materials } & 37\end{array}$

3.3.1.2 Method 38

3.3.2 Determination of Protein Efficiency Ratio-Steamed cereals $\quad 39$

3.3.2.1Sample preparation for steamed cereals $\quad 39$

$\begin{array}{ll}\text { 3.3.2.2 Method } & 39\end{array}$

3.4 Determination of Anti-nutrients in cereals 40

3.4.1 Determination of Phytate in cereals $\quad 40$

3.4.1.1 Materials $\quad 40$

$\begin{array}{ll}\text { 3.4.1.2 Method } & 40\end{array}$

3.5 Statistical analysis $\quad 43$

Chapter 04 Results and Discussion

4.1 Proximate composition, $\mathrm{Ca}, \mathrm{Fe}$ and $\mathrm{P}$ of cereal samples 44

4.2 Protein Efficiency Ratios of minor cereals $\quad 45$

4.2.1 Protein Efficiency Ratios in raw cereals $\quad 45$ 
4.2.2 Protein Efficiency Ratios in steamed cereals

4.2.3 Protein efficiency ratios of raw and steamed samples

4.2.3.1 Reference samples

4.2.3.2 Kurakkan samples

4.2.3.3 Sorghum samples 50

4.2.3.4 Thanahal samples

4.2.3.5 Meneri samples

4.3 Phytate analysis of minor cereals

Chapter 05 Conclusions

5.1 Conclusions

5.2 Recommendations for further work

\section{References}




\section{List of Tables}

Table 2.1 Average composition of proso millet in dry basis $(\mathrm{g} / 100 \mathrm{~g})$.

Table 2.2 The average composition of foxtail millet hay and its comparison

to other hay crops

Table 3.1 Cooking time and water amount for better quality cooking of cereals 41

Table 4.1 Proximate analysis, $\mathrm{Ca}, \mathrm{Fe}$ and $\mathrm{P}$ results of minor cereals 44

Table 4.2 Weight gain of rats at weekly intervals 45

Table 4.3 PER values of raw cereal as measured 46

Table 4.4 Weight gain of rats in weekly intervals 47

Table 4.5 PER values of steamed cereal as measured 48

Table 4.6 Average phytate values in raw, steamed and cooked cereals 51 


\section{List of Figures}

Fig. 2.1 Eleusine coracana $L$

Fig. 2.2 Inflorescence of Eleusine coracana $L$

Fig. 2.3 Grains of Eleusine coracana 5

Fig. 2.4 Finger millet in its commonly consumed form as porridge 7

Fig. 2.5 Panicum miliaceum L.

Fig. 2.6 Seeds of Panicum miliaceum L 10

Fig. 2.7 spikelet of Panicum miliaceum 10

Fig. 2.8 Sorghum vulgare L 13

Fig. 2.9 Red sorghum and sorghum snack 17

Fig. 2.10 Setaria italica $L$

Fig. 2.11 Structure of phytic acid 25

Fig.2.12 Protein bound to phytate molecule 26

Fig 2.13 Phytase amount and protein digestability 28

Fig 4.1 Average weight gain of rat 45

Fig 4.2 Protein efficiency ratios of raw cereals 46

Fig 4.3 Average weight gain of rat with steamed cereals 47

Fig 4.4 Protein efficiency ratios of steamed cereals 48

Fig 4.5 Protein efficiency ratios of raw and steamed cereals 49

Fig 4.6 Variation of phytate levels in cereals with processing 52 


\section{Acknowledgements}

I wish to express my deepest gratitude to my external supervisor Mrs.Damitha Rajapaksha, Dr.Sagarika Ekanayake and to my internal supervisor Dr.K.K.D.S.Ranaweera for their assistance, encouragement and generous support during the period of work.

Also I would like to thank specially Dr.Shamani Jayasekara and other staff at Medical Research Institute, who were willing to give there support and assistance to me throughout animal study.

A special word of thanks to all the staff of Food Technology Division, Industrial Technology Institute and all the staff of Biochemistry department, Faculty of Medicine for their kind assistance during the research works.

Finally, I would like to thank all the members of the academic staff of Department of Food Science and Technology, University of Sri Jayawardenapura for their comments and suggestions to improve the quality of this research work and also I would like to thank all people who were willing to give there support and assistance to me through out my project. 


\title{
Proximate Composition and Effect of Processing on Protein Quality of Minor Cereals Grown in Sri Lanka
}

\begin{abstract}
Kurakkan (Eleucine coracana), Meneri (Panicum missiaceum), Sorghum (Sorghum vulgare) and Thanahal (Setaria italica) are underutilized minor cereals in Sri Lanka. These varieties are recommended to be grown in Sri Lanka by Field Crop Research Development Institute at Mahaillupallama as a source of energy and protein. This study was undertaken in order to determine the chemical composition, the effect of processing on Protein Efficiency Ratio and antinutrients of of Kurakkan (Ravi), Meneri (AC254), Sorghum (ICSR 94002) and Thanahal (935).
\end{abstract}

Chemical analysis and determination of Protein Efficiency Ratio (rat bioassay) of minor cereals were carried out according to the AOAC official methods. Carbohydrate levels of minor cereals varied from $71.00-80.52 \mathrm{~g} / 100 \mathrm{~g}$ and crude fiber level of minor cereals ranged from $0.52-2.54 \mathrm{~g} / 100 \mathrm{~g}$. Low levels of fat $(1.47,1.91 \mathrm{~g} / 100 \mathrm{~g})$ were seen in kurakkan and meneri while high levels of fat $(2.76,4.6 \mathrm{~g} / 100 \mathrm{~g})$ were seen in sorghum and thanahal respectively. Protein contents were 7.7, 12.8, 7.8 and 13.8g/100g in Kurakkan, Meneri, Sorghum and Thanahal respectively. The average weight gain of rats were significantly lower than in the group fed the reference diet $(\mathrm{p} \leq 0.05)$ and the estimated Protein Efficiency Ratios of raw Kurakkan, Meneri, Sorghum and Thanahal were $0.24 \pm 0.09,0.15 \pm 0.03,0.50 \pm 0.33$ and $0.20 \pm 0.09$ respectively which were significantly lower than the reference casein $(p \leq 0.05)$. In steamed cereals the values were $0.26 \pm 0.07$, $0.17 \pm 0.06, \quad 0.54 \pm 0.21$ and $0.21 \pm 0.09$ with no significant $(\mathrm{p} \geq 0.05)$ different from rawrespectively. The phytate amounts of raw and steamed Kurakkan, Meneri, Sorghum and Thanahal were 1.45, 0.76, $1.280 .67 \mathrm{mg} / 100 \mathrm{~g}$ and $1.44,0.78,1.31$ and $0.70 \mathrm{mg} / 100 \mathrm{~g}$ respectively. The phytate amounts were significantly $(\mathrm{p} \leq 0.05)$ reduced by soaking and cooking and values were $0.92,0.70,1.07$ and $0.52 \mathrm{mg} / 100 \mathrm{~g}$ respectively.

The results confirmed low protein digestibility and bioavailability of raw and steamed cereals and indicated that protein quality is not improved by steaming only. It is expected that soaking and cooking will increase the protein quality because according to above results the phytate amount of thus processed cereals were reduced. 


\section{Chapter 01 \\ INTRODUCTION}

\subsection{Introduction}

Sri Lanka is blessed with a wide variety of cereals, legumes, fruits and vegetables which can be successfully utilized in the formulation of foods. Minor cereals are main staples of the poor and most insecure people in African countries. These cereals are also favored among Sri Lankan people due to its value as health foods. Kurakkan (Eleucine coracana), Meneri (Panicum miliaceum), Sorghum (Sorghum vulgare) and Thanahal (Setaria italica) are underutilized minor cereals in Sri Lanka. The nutritive values are comparable with other staple cereals like wheat and rice, while some of them are even better with regards to average protein, fat and mineral contents. Therefore these are recognized as important substitutes for food shortage and meet the demand of increasing population in Sri Lanka. Kurakkan (Ravi), Meneri (AC254), Sorghum (ICSR 94002) and Thanahal (935) varieties are recommended to be grown in Sri Lanka by Field Crop Research Development Institute at Mahaillupallama, but their utilization is limited and data on nutrient composition and antinutrients are not available for these varieties.

The reasons for limited utilization of these in Sri Lanka are the presence of antinutrients, poor digestibility of protein, carbohydrate and low palatability of these minor cereals. The sensory properties of these cereals are poor due to there coarse nature of grains and also flour due to the high fiber content. These are rich in poly phenols which influence the color and flavor. The limited availability of refined and processed millets in ready to use form has further limited use and acceptability.

These minor cereals are rich in phytic acid which is a strong chelator of important minerals such as calcium, magnesium, iron, and zinc, and therefore contribute to mineral deficiencies in people whose diets rely on these foods for their mineral intake, such as those in developing countries. It also acts as an acid, chelating the vitamin niacin, which is basic, causing the condition known as pellagra. Some nutritional studies have suggested that phytate also affects protein utilization. However, various processing treatments are known to affect the chemical composition and improve nutritive value of foods. 
The present study was carried out to study the proximate composition, mineral content, the improvement in protein availability when subjected to different processing treatments and certain antinutritional compounds such as phytate. This could help to increase the protein quality of cereals. So that these could be used to improve the protein intake by incorporating into various products.

\subsection{Objectives}

This study was carried out with the main objective of determining the effect of processing methods on protein availability of kurakkkan (Eleucine coracana) -Ravi, Meneri (Panicum milliaceum) - AC254, Thanahal (Setaria italica) - 935 and Sorghum (Sorghum vulgare) - ICSR 94002 and selection of suitable methods for product development.

\subsubsection{Specific Objectives}

i. Determination of proximate composition, $\mathrm{Fe}, \mathrm{Ca}$ and $\mathrm{P}$ content of selected varieties of minor cereals.

ii. Determination of protein efficiency ratio (PER) of raw cereals and processed cereals. Processing methods- steaming soaking and cooking etc...

iii. Determination of anti-nutrients in raw and processed cereals. 


\section{Chapter 02}

\section{Review of literature}

\subsection{Kurakkan - (Eleucine coracana)}

\subsubsection{Introduction}

Kurakkan (Eleusine coracana) or finger millet (red millet) is one of the important cereal crops of the chenas in the dry zone. It belongs to family Poaceae. Finger millet is the second most important millet in Africa after pearl millet. Its nutritive value is very high especially protein, fat and minerals when compaired with rice and maize. There are many varieties and the varietal difference of kurakkan is based on the period of maturity, habit of growth, size, shape and color of earheads, yealding capacity, size and quality of the grain. Kurakkan starch is hydrolyzed in the gastrointestinal tract more slowly than rice starch and prescribed for diabetic patients (Rao, 1994).

In Sri Lanka, Kurakkan has been cultivated from earliest times and is considered as the second staple after rice and is one of the important cereal crops in the dry zone.

\subsubsection{Habitat and distribution}

Eleusine coracana is found in warm temperate regions of the world from Africa to Japan and also in Australia. It is present in archaeological records of early African agriculture in Ethiopia that date back 5000 years, and it probably originated somewhere in the area that today is Uganda. It is an important staple crop in many parts of Africa and has been cultivated in eastern and southern Africa since the beginning of the iron age. Before maize was introduced it was the staple crop of the southern African region. It was introduced to India some 3000 years ago (National Research Council 2008).

The wild form is found in areas with rainfall as low as $300 \mathrm{~mm}$ per annum in South Africa, but the cultivated form more commonly requires 500-1000 mm of rainfall per year. This should be well-distributed throughout the growing season and with an absence of prolonged droughts. The altitude limits of the species are unknown, but most of the cultivated finger millet in the world is found from 500-2400 m elevation. It tolerates cool climates, but thrives under hot conditions and can grow where temperatures are as high as $35^{\circ} \mathrm{C}$. Eleusine coracana appears to be photoperiod sensitive, the optimum 
photoperiod being 12 hours, which is considered to be relatively short (National Research Council 2008).

\subsubsection{Botany of the plant}

\subsubsection{Taxonomy}

There are about 9 species occurring in tropical and subtropical parts of the world.

$\begin{array}{ll}\text { Kingdom } & \text { : Plantae } \\ \text { Division } & : \text { Magnoliophyta } \\ \text { Class } & : \text { Liliopsida } \\ \text { Order } & : \text { Poales } \\ \text { Family } & : \text { Poaceae } \\ \text { Subfamily } & : \text { Chloridoideae }\end{array}$

Genus : Eleusine

Species : E. coracana

Vernacular names: Tailabon (Arabic), Finger millet, African millet, ragi, koracan (English), eleusine cultivee, coracan, koracan (French), in India Ragi (Kannada, Telugu), Taidalu (Telangana), Kelvaragu,Aariyam (Tamil), Kurakkan (Sri Lanka), Hong mi, Chi ke (Vietnam), Fingerhirse (Denmark) (Rajapaksha, 1998).

\subsubsection{Description and Morphology}

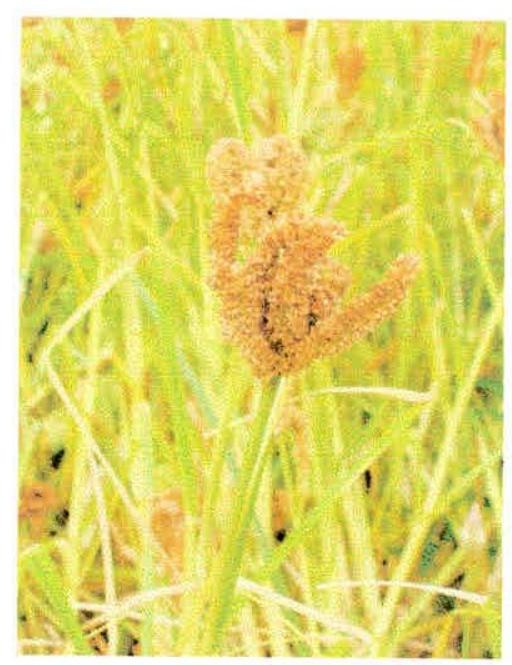

Fig. 2.1 Eleusine coracana $L$ 